\title{
16. NEOGENE PALYNOLOGY FROM THE SOUTHERN CALIFORNIA CONTINENTAL BORDERLAND, SITE 467, DEEP SEA DRILLING PROJECT LEG $63^{1}$
}

\author{
Robert A. Ballog and Raymond E. Malloy, Union Oil Company of California, \\ Ventura, California
}

\section{INTRODUCTION}

Neogene palynofloras of southern California have been all too infrequently studied. Previous investigations of Pacific Coast sediments have been largely restricted to Pacific Northwest locales. Some important studies include those by Gray (1964), Wolfe, Hopkins, and Leopold (1966), Wolfe and Leopold (1967), Hopkins (1968), Piel (1969, 1977), Ballog, Sparks, and Waloweek (1972), and Musich (1973). The only published study of southern California materials is that of Heusser (1978) on Holocene sediments of the Santa Barbara basin. Most of these studies are concerned with the microflora from a particular formation; thus they have limited stratigraphic value and in most cases involve nonmarine to marginal marine rocks where no planktonic zonation was available. Musich's (1973) study was the first attempt at tying pollen assemblages to a planktonic zonation over an extended stratigraphic interval (Miocene to Pleistocene).

Its location in the southern California Borderland (Fig.1) and the sedimentary sections sampled make Leg 63 extremely valuable in deciphering the palynologic history of the Pacific Coast Neogene. Site 467 was chosen for our initial detailed study, because the relatively slow sedimentation rate provides an almost complete Neogene sequence of mainly terrigenous sediments and reliable planktonic age control is available.

The goals of this study were to: (1) establish a reference section of Neogene palynomorph assemblages; (2) develop biostratigraphic criteria for use in correlation with other localities; (3) correlate the palynologic assemblages with the planktonic zonations; and (4) study the paleoenvironmental history in the southern California Neogene.

\section{METHODS}

A total of 134 samples were examined for this study. At least 20 $\mathrm{cm}^{3}$ of material were taken to insure adequate palynomorph recovery. The samples were processed using standard palynologic techniques. After treatment with $\mathrm{HCl}$ to remove any carbonate, the samples were then treated in $70 \%$ HF for approximately 16 hours. They were then treated successively with concentrated $\mathrm{HCl}, \mathrm{HNO}_{3}$, and $\mathrm{NH}_{4} \mathrm{OH}$. These steps were followed by a heavy-liquid separation using zinc bromide and a short immersion in an ultrasonic generator. The Safranin-stained residue was then mounted on coverslips with polyvinyl alcohol and allowed to dry. The coverslip was secured to the microslide using an epoxy cement.

\footnotetext{
${ }^{1}$ Initial Reports of the Deep Sea Drilling Project, Volume 63.
}

We attempted to identify palynomorphs to the generic level whenever possible. However, several groups were identified only to family level. These include Chenopodiaceae, Rhamnaceae, Gramineae, Anacardiaceae, Compositae, Elaegnaceae, Polemoniaceae, Bombacaceae, Malvaceae, Onagraceae, and Caryophyllaceae. Also, Taxodiaceae, Cupressaceae, and Taxaceae were lumped into what we called the Taxo Group. We identified species of Ambrosia and members of the Compositae family separately and also grouped all Compositae except Artemisia into Asteraceae for use in our computer analyses. In addition, we lumped all spores and all dinoflagellates into two groups for purposes of interpretation.

We determined the abundance by counting all palynomorphs observed under the $20 \times 40 \mathrm{~mm}$ coverslip; we attempted to count a minimum of 100 grains for each sample scrutinized. Table 1 lists the actual count of selected species encountered in Hole 467. Figure 2 is a sawblade diagram of 18 selected types. The abundance percentages plotted for the first 16 types on Figure 2 are calculated against the total number of all angiosperms and gymnosperms in each sample. Pteridophyte spores, dinoflagellates, acritarchs, microforaminifers, and algal bodies are excluded from this sum. The last two groups to the right on Figure 2 are total spores and total dinoflagellates, each plotted as a percentage of the total assemblage.

Statistical analysis of the data was undertaken using both Q-mode and R-mode cluster analysis programs. Q-mode, or normal analysis, involves the comparison of samples based upon their contained species; $\mathrm{R}$-mode, or inverse analysis, involves the comparison of species based upon the samples in which they occur. Q-mode yields stratigraphic information, whereas R-mode is used primarily for paleoenvironmental determinations. The data was standardized using a species mean standardization and the Bray-Curtis coefficient for the Q-mode analysis, and a species maximum standardization with the Bray-Curtis coefficient for the R-mode analysis. These standardizations have been shown to be particularly useful when working with biological data (Smith, 1976). The matrix used for both analyses was initially transformed using a square-root transformation. The resultant analyses were plotted on a two-dimensional dendrogram.

\section{SITE 467}

$\left(33^{\circ} 50.97^{\prime} \mathrm{N}, 120^{\circ} 45.47^{\prime} \mathrm{W}\right.$; depth $\left.2127.8 \mathrm{~m}\right)$

Site 467 is located at San Miguel Gap in the outer California Continental Borderlands, near the eastern boundary of the California Current. A relatively complete section of Quaternary to middle Miocene is present and has been subdivided into four lithologic units.

Unit 1 consists of silty clay and diatomaceous nannofossil clay extending from the surface to 367 meters. Unit 2 extends from 367 to 699.5 meters and consists of claystone that becomes more lithified with depth. Unit 3 , between 699.5 and 832.5 meters, is a pumiceous lapilli tuff interbedded with nannofossil-clayey chalk, limestone, and claystone. Unit 4, from 832.5 to 1041.5 meters, resembles Unit 2 in consisting of interbedded clayey chalk and calcareous claystone with minor thin beds of fine-grained quartzo-feldspathic sandstone.

Palynomorphs were recovered from all four units, although their abundances decrease somewhat with 


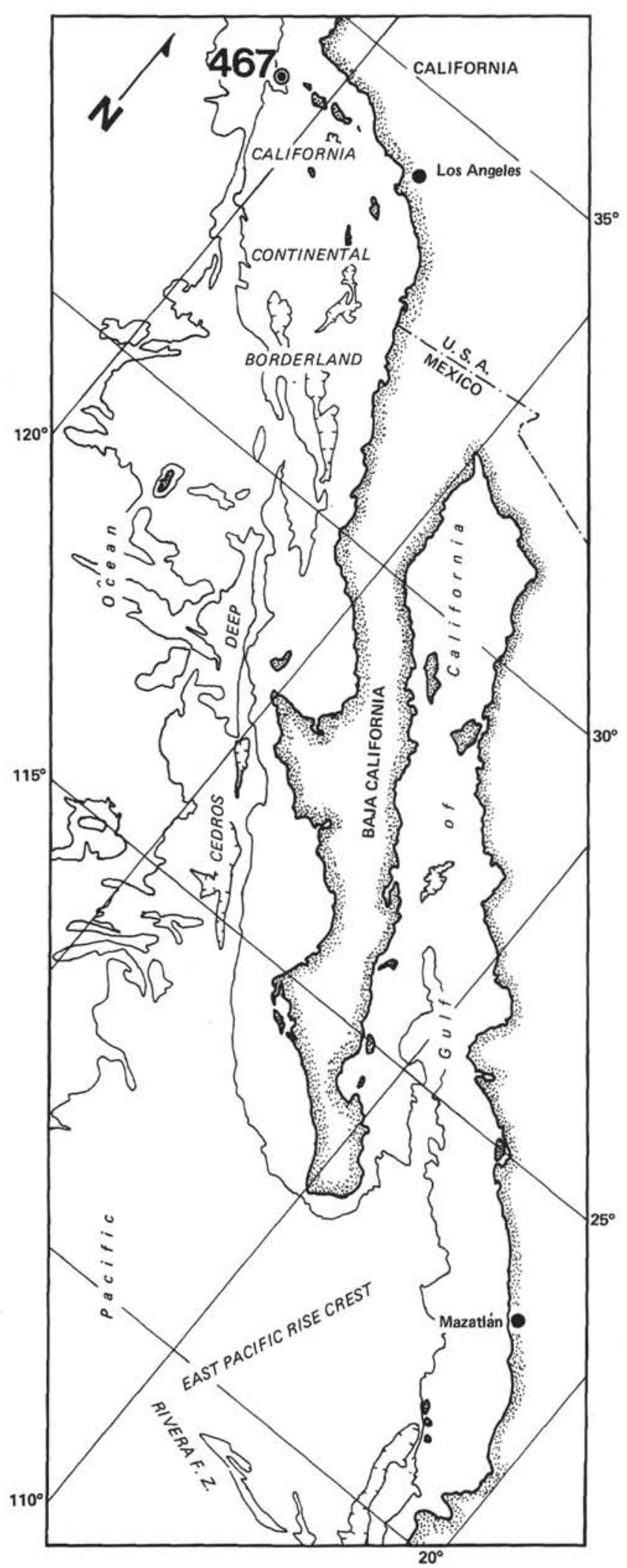

Figure 1. Location map, Site 467. depth. The diagenetic break from clay to claystone at 367 meters has had no apparent effect, however, on the relative abundance of palynomorphs.

\section{STRATIGRAPHIC RESULTS}

Because there are few stratigraphically restricted pollen species in the Neogene section of Hole 467, many of our biostratigraphic conclusions are based in large part on abundance data. With rare exceptions, most of the restricted ranges found in Hole 467 imply climatic variations and are not evolutionary extinctions. Thus, comparison of ranges of similar taxa from different areas is not a successful method of correlation for most Neogene pollen species. However, comparing abundance ranges using relative abundance curves or sawblades is a useful method of deciphering climatic conditions and comparing different stratigraphic sections within the same or adjacent basins. The most useful species of biostratigraphic correlation are the dinoflagellates, because they do provide some degree of interregional correlation within the Neogene.

In Hole 467, the genera that appear to have stratigraphically important ranges include: Artemisia, Ambrosia, Eriogonum, Cannosphaeropsis sp. A., and Operculodinium sp. 1. Artemisia evolved on a worldwide basis in the late Miocene to become a significant component of most temperate and/or xeric climates. In Hole 467 Artemisia's earliest stratigraphic occurrence is within the upper Miocene $A$. primus Subzone of the $D$. quinqueramus Zone (Sample 52,CC), and it varies from $1 \%$ to $5 \%$ within the uppermost Miocene, Pliocene, and Quaternary. Another stratigraphically important member of the Compositae is Ambrosia. For this study we have separated Ambrosia into two species-sp. 1 and sp. 2. Both species range from the upper Miocene $D$. variabilis Zone through the Quaternary. The first appearances of both Artemisia and Ambrosia are significant points and can be used to date Neogene sediments throughout the Pacific Coast region. The third restricted pollen species Eriogonum, present only in Pliocene and younger sediments, has its first occurrence in Sample 43,CC. We do not know at this time if this earliest occurrence is of widespread regional significance, but it should prove useful within this area.

Two dinoflagellates have stratigraphically significant ranges within Hole 467. One, Cannosphaeropsis sp. A., of Williams and Brideaux (1975) is a zonal marker for the upper Miocene of the Grand Banks and Scotian Shelf (Williams and Bujak, 1977). This species has its last stratigraphic occurrence within the $A$. primus Subzone of the A. tricorniculatus Zone in Hole 467 (Sample $41, \mathrm{CC})$, and we propose that this species may be useful as a guide fossil for the uppermost Miocene on the Pacific Coast. The other dinoflagellate, Operculodinium sp. 1, is an undescribed variant of Operculodinium centrocarpum (see Harland, 1973, plate 2, figs. 13-15) that has its last stratigraphic occurrence in Sample 45, CC within the upper Miocene A. primus Subzone of 
the $A$. tricorniculatus Zone. Additional studies are needed to document firmly the ranges of these two species, but it appears that they are important markers.

As stated above, abundance ranges provide much of the useful data for biostratigraphic control within the Neogene. As seen in Figure 2, Pinus constitutes about $50 \%$ of the total flora, with the Taxo Group and Quercus also dominant members of the flora. Within the upper Miocene, Pliocene, and Quaternary, both Chenopodiaceae and Asteraceae become important taxa. Chenopodiaceae become significant at 550 meters, in the upper Miocene, and remain abundant throughout the Pliocene and Quaternary. Asteraceae first become an important part of the flora at 625 meters and from there to 296 meters average $3 \%$ of the flora. From 276 meters to the top of the hole, Asteraceae increase to greater than $5 \%$ abundance. Artemisia, while never abundant, becomes statistically significant at 484 meters and averages between $1 \%$ and $5 \%$ through the Pliocene and Quaternary. Other important abundance trends include the increase in abundance downhole of Juglans and Castanea within the upper Miocene $D$. variabilis Zone and continuing down into the middle Miocene. Carya also is more abundant in the middle Miocene C. miopelagicus and $S$. heteromorphts Zones.

As stated previously, abundance peaks reflect climatic influences; we thus established biostratigraphic boundaries on the basis of climatic changes. Assuming that we correctly observed regional floral and climatic changes, the boundaries we established should correlate throughout the southern California Borderland.

One final abundance trend that is important is the decrease in abundance of total dinoflagellate percentage from $10 \%$ or greater within the late Miocene and older to less than $2 \%$ in the Pliocene and younger sediments. We will discuss this decrease later under paleoenvironment but should stress here that this important biostratigraphic event has been observed in other southern California Borderland sites.

It is important to note that both of the stratigraphically restricted dinoflagellate cyst species Cannosphaeropsis $\mathrm{sp}$. A. and Operculodinum sp. 1 disappear from the section at points well above the sharp decrease in total dinoflagellate percentage (see Table 1 and Fig. 2). This suggests that if ecologic factors responsible for the decrease in dinoflagellate abundance did not restrict these two species, then their respective last-occurrence "tops" may well be evolutionary extinctions.

For stratigraphic purposes, a Q-mode cluster program is used to compare samples against each other. On the Q-mode dendrogram (Fig. 3) we can see four distinct groupings. These groups are divided as follows: Group I, Pliocene and Quaternary samples; Group II, a mixed group of upper Miocene and Pliocene samples; Group III, upper Miocene samples; and Groups IV, middle Miocene samples. It should be noted that the Pliocene and Quaternary samples group together. Based on this data as well as data from Table 1 and Figure 2, it can be seen that palynologically we cannot separate the Pliocene from the Quaternary in this area. The lumping together, in Group II, of upper Miocene and Pliocene samples is probably the result of low diversity samples.

The R-mode cluster dendrogram, Figure 4, also contains four distinct groupings. Group A is composed of the three dominant long-ranging taxa observed in this study. Group B is a grouping of primarily xerophytic genera that predominate in the Pliocene through Quaternary samples. The taxa that compose Group $\mathrm{C}$ occur most abundantly within the Miocene, and Group D comprises less abundant and more cosmopolitan Pliocene and Miocene taxa.

Combining the data from both the Q-mode and $\mathrm{R}$-mode analyses enables us to obtain an idea of which species are most important in forming the groupings shown in Figure 3. The species important in defining Group I include those from Group B. These are mainly xerophytic types either restricted to or most common within the Pliocene and Quaternary. The major break shown between Groups I and II and Groups III and IV is the result of the species from Group $\mathrm{C}$ becoming more important in the Miocene.

\section{PALEOENVIRONMENTAL RESULTS}

From previous work (Heusser, 1978), we know that the late Quaternary is climatically very similar to the present. The data gathered in this study indicates that this climate persisted from at least early Pliocene. The presence of significant percentages of Quercus, Chenopodiaceae, and Asteraceae as well as the minor but consistent representation of Eriogonum, Rhamnaceae, and Ephedra shown in Figure 2 indicate that the coastal sage scrub, chaparral, and oak grassland communities were intact throughout the Pliocene. An absence of Picea, Tsuga, and Sequoia pollen indicates that not only has southern California been relatively climatically static since the Pliocene, but that elements from the Northwest Pacific Coast flora (Musich, 1973) have not been transported south by the California Current. The absence of Picea also possibly indicates a moderate elevation for the onshore highlands surrounding the drainage area of Site 467.

In the late Miocene we see a climatic change from the wetter, more humid climate to a more xeric climate of the Pliocene through Quaternary. This is shown by the increase in abundance of the Chenopodiaceae and Asteraceae and the presence of Eriogonum, as well as by the decrease in abundance of several warm temperate genera including Juglans, Castanea, and Carya. The increased abundance of these genera in the Miocene is probably indicative of the change from summer-wet conditions to the summer-dry conditions prevailing from Pliocene through Recent.

These conclusions relate to the onshore environment, but one important fact regarding the marine environment has been noted in Hole 467: the decrease in abundance and diversity of dinoflagellates within the late Miocene. This was mentioned earlier as an important stratigraphic datum because it has been observed in other offshore sites. It is also important environmentally as an indication of a change in surface waters. Al- 
Table 1. Species abundance chart, Site 467.

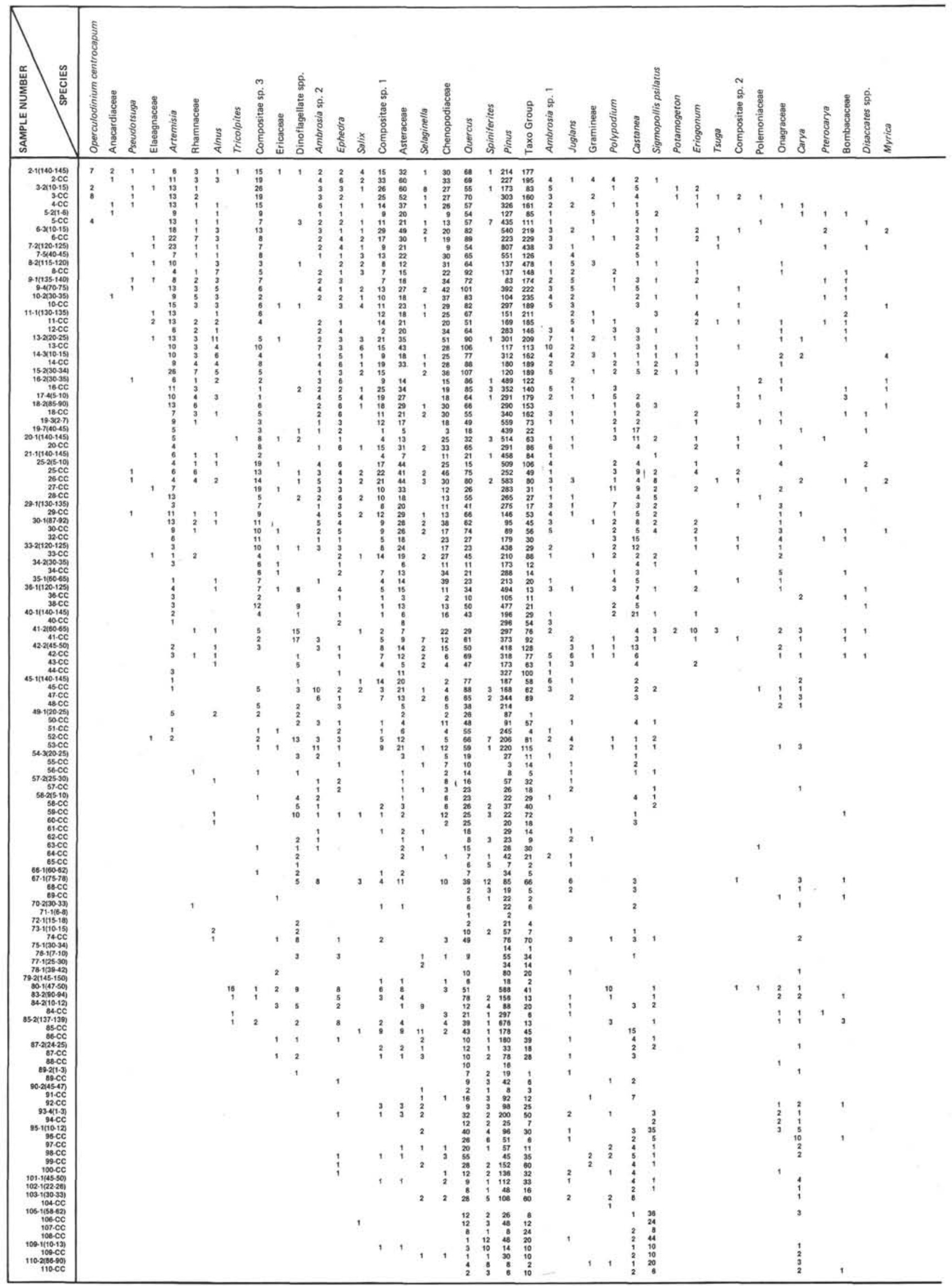


Table 1. (Continued).

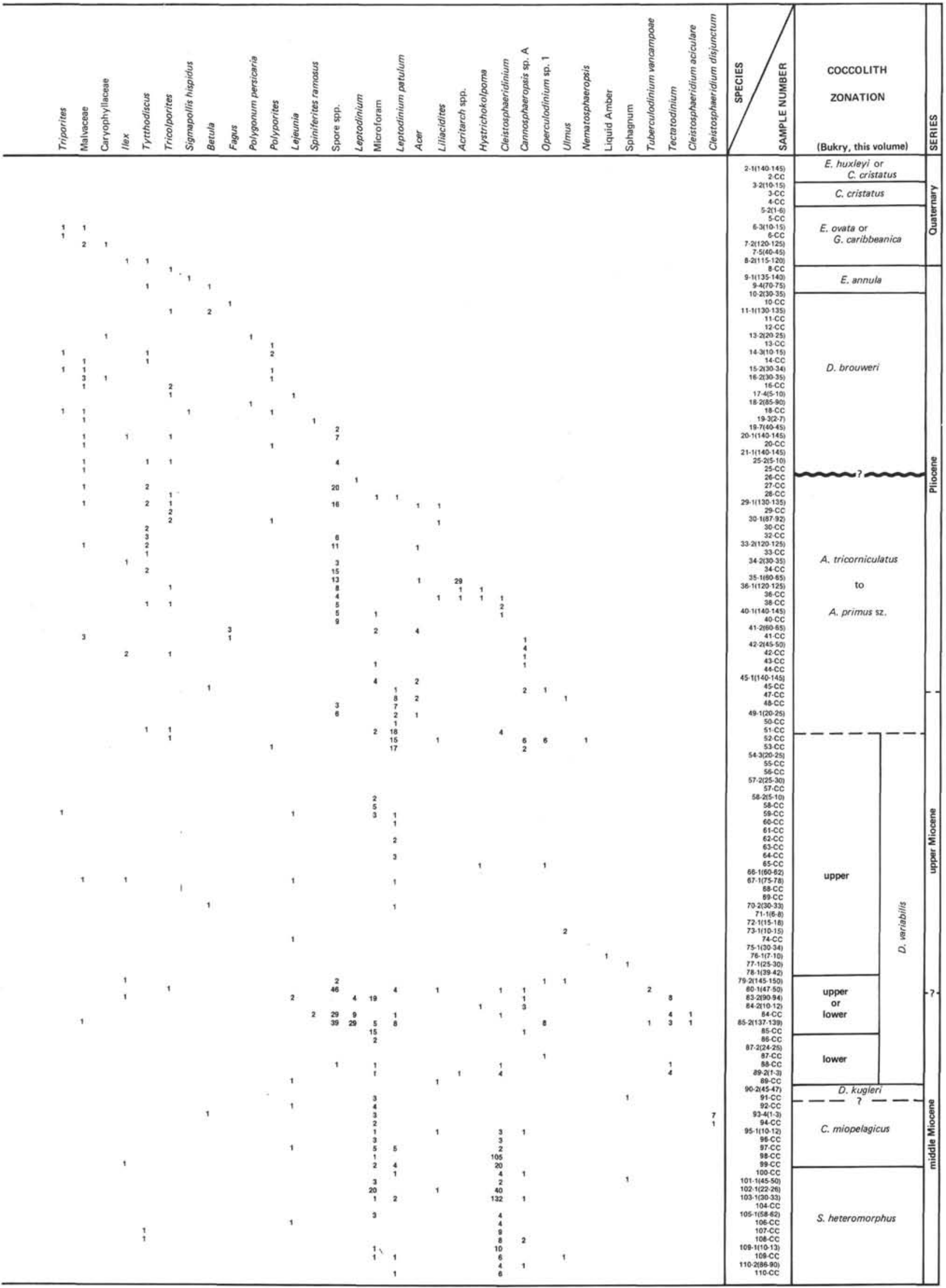




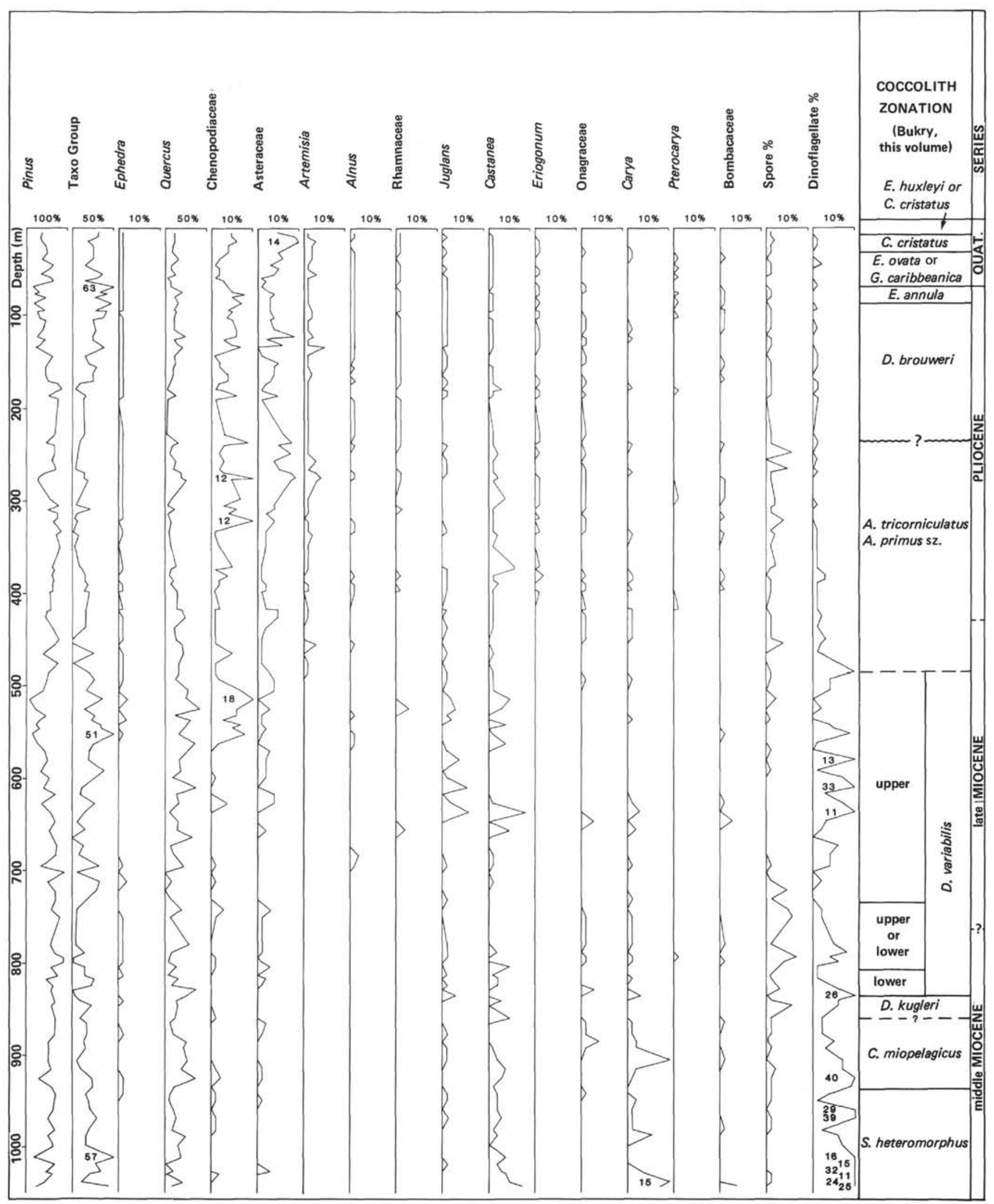

Figure 2. Sawblade diagram, Site 467. 


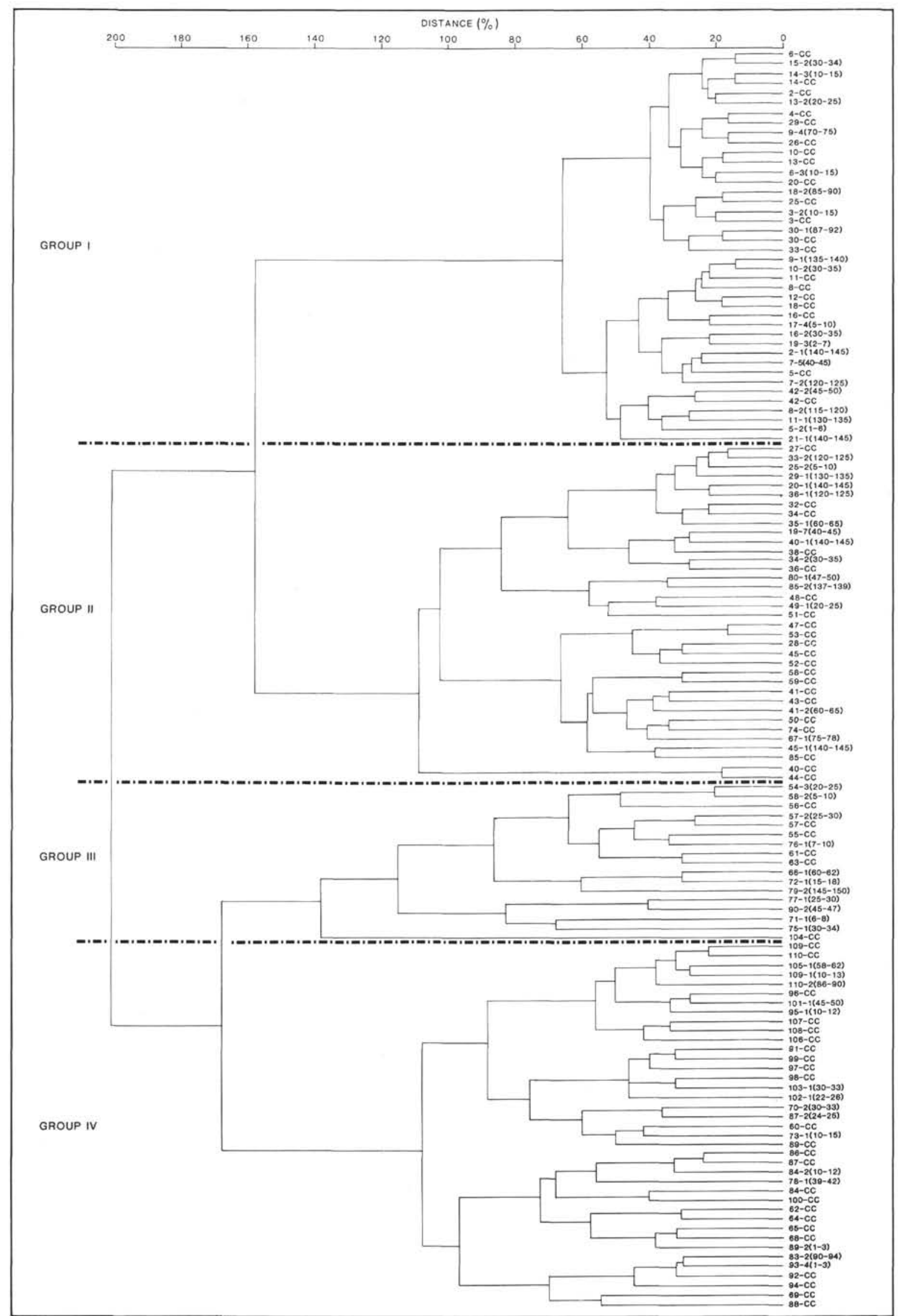

Figure 3. Q-mode cluster diagram, Site 467. 


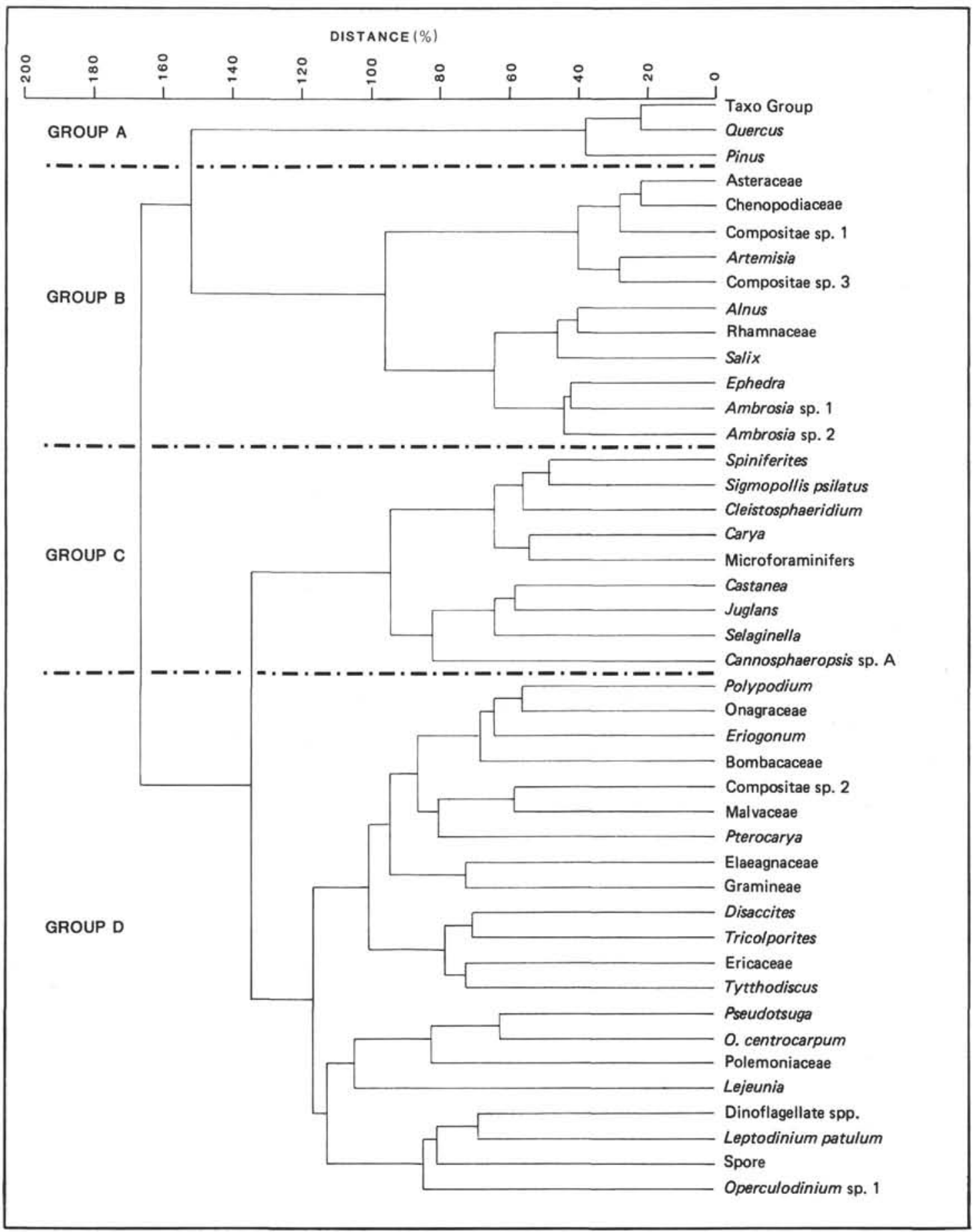

Figure 4. R-mode cluster diagram, Site 467.

though dinoflagellate cyst paleoecology is at this time inadequately understood, some recent ecologic data are available (Wall et al., 1977). Dinoflagellates live in the photic zone and their encystment is the result of either physical and/or biological stimuli. Whatever the exact cause, the abundance of dinoflagellate cysts in the sediments is assumed to be a reflection of dinoflagellate abundance in the overlying surface waters; Wall et al. (1977) have shown that this abundance is related to surface water composition. We interpret this change in abundance and diversity within the late Miocene to reflect a major shift in the surface waters, possibly a change in location, composition, and/or temperature of the California Current. A relative change from warm to cool surface temperatures has been noted at approximately this same level in Hole 467 on coccolith evidence (Bukry, this volume). Other disciplines, including radiolarians, diatoms, and planktonic foraminifers, have noted this change in water mass composition in other studies of offshore California sites (Ingle, 1973). 


\section{CONCLUSIONS}

The data from Hole 467 provide us with our first indepth study of palynologic assemblages from the southern California Neogene. Our preliminary biostratigraphic conclusions are: (1) Artemisia and Ambrosia are markers for late Miocene through Recent sediments; (2) Eriogonum appears to be a marker for the Pliocene through Recent; (3) Carya decreases significantly in abundance after the middle Miocene; (4) the extinction of Cannosphaeropsis sp. A., of Williams and Brideaux (1975) appears useful as a marker for the late Miocene; and (5) a decrease in abundance of the total dinoflagellate percentage within the late Miocene is an important biostratigraphic event. Figure 5 is a correlation of these events with the biostratigraphic zonations of coccoliths, radiolarians, and diatoms for Hole 467.

Conclusions regarding the environmental results include: (1) Pliocene climatic conditions persisted through the Quaternary; (2) during the Pliocene we see a change to summer-dry conditions from the previous summerwet conditions of the Miocene; and (3) the decrease in dinoflagellate abundance during the late Miocene denotes a change in surface waters from warm within the Miocene to cool in the Pliocene through Quaternary.

\section{ACKNOWLEDGMENTS}

The authors are grateful to Union Oil Company for permission to carry out this project. We would like to thank David R. Vork who assisted us extensively both in counting samples and running the computer analyses. We would also like to thank Dr. Kenneth M. Piel and Mr. Harry A. Leffingwell for reviewing this manuscript and offering many helpful suggestions. Special thanks go to Mary Meena for her typing skills and to Vic Meyer who drafted the figures.

\section{REFERENCES}

Ballog, R. A., Sparks, D. M., and Waloweek, W., 1972. Palynology of the Montesano Formation (upper Miocene) of western Washington. In Stinemeyer, E. H. (Ed.), Pacific Coast Miocene Biostratigraphic Symposium: Pacific Coast Section SEPM, pp. 199-212.
Gray, J., 1964. Northwest American Tertiary palynology. The emerging picture. In Cranwell, L. M. (Ed.), Ancient Pacific Floras: Honolulu (University of Hawaii Press), pp. 21-30.

Harland, R., 1973. Quaternary (Flandrian?) dinoflagellate cysts from the Grand Banks, off Newfoundland, Canada. Review of Palaeobotany and Palynology, 16:229-242.

Heusser, L., 1978. Pollen in Santa Barbara Basin, California: a 12,000 yr. record. Geol. Soc. Am. Bull., 89:673-678.

Hopkins, W. S., Jr., 1968. Subsurface Miocene rocks, British Columbia-Washington, a palynological investigation. Geol. Soc. Am. Bull., 79:763-768.

Ingle, J. C., Jr., 1973. Summary comments on Neogene biostratigraphy, physical stratigraphy, and paleoceanography in the marginal northeastern Pacific Ocean. In Kulm, L. D., von Huene, R., et al., Init. Repts. DSDP, 18: Washington (U.S. Govt. Printing Office), 949-959.

Musich, L. F., 1973. Pollen occurrence in eastern North Pacific sediments, Deep Sea Drilling Project Leg 18. In Kulm, L. D., von Huene, R., et al., Init. Repts. DSDP, 18: Washington (U.S. Govt. Printing Office), 799-815.

Piel, K. M., 1969. Palynology of middle and late Tertiary sediments from the central interior of British Columbia, Canada [Ph.D. dissert.]. University of British Columbia.

, 1977. Miocene Palynological Assemblages from Central British Columbia. In Elsik, W. C. (Ed.), Contributions of Stratigraphic Palynology (Vol. 1), Cenozoic Palynology: Houston (American Association of Stratigraphic Palynologists), 91-110.

Smith, R. W., 1976. Numerical analysis of ecological survey data [Ph.D. dissert.]. University of Southern California.

Wall, D., Dale, B., Lohmann, G. P., et al., 1977. The environmental and climatic distribution of dinoflagellate cysts in modern marine sediments from regions in the North and South Atlantic Oceans and adjacent seas. Mar. Micropaleontol., 2:121-200.

Williams, G. L., and Bujak, J. P., 1977. Cenozoic palynostratigraphy of offshore eastern Canada. In Elsik, W. C. (Ed.), Contributions of Stratigraphic Palynology (Vol. 1), Cenozoic Palynology: Houston (American Association of Stratigraphic Palynologists), 14-47.

Wolfe, J. A., 1969. Neogene floristic and vegetational history of the Pacific Northwest. Madrono, 20:83-110.

1971. Tertiary climatic fluctuations and methods of analysis of Tertiary floras. Palaeogeogr., Palaeoclimatol., Palaeoecol., 9:27-57.

Wolfe, J. A., Hopkins, D. M., and Leopold, E., 1966. Tertiary stratigraphy and paleobotany of the Cook Inlet region, Alaska. U.S. Geol. Surv. Prof. Pap. 398-A: Washington (U.S. Govt. Printing Office), pp. A-1-A-29.

Wolfe, J. A., and Leopold, E., 1967. Neogene and early Quaternary vegetation of northwestern North American and northeastern Asia. In Hopkins, D. M. (Ed.), The Bering Land Bridge: Stanford, California (Stanford University Press), pp. 193-206. 


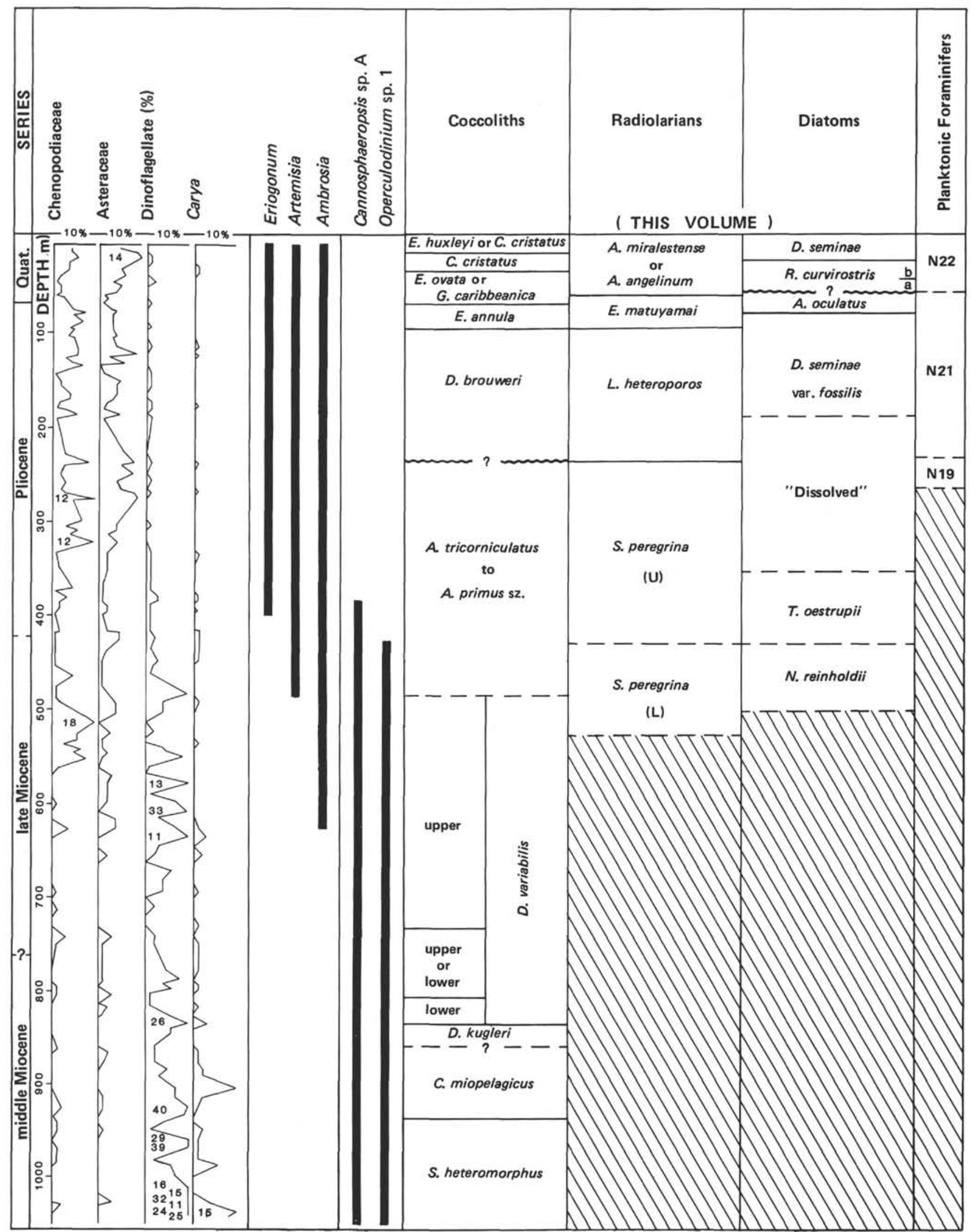

Figure 5. Correlation of palynologic markers and planktonic zonations, Site 467. 


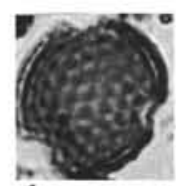

1

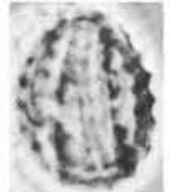

2

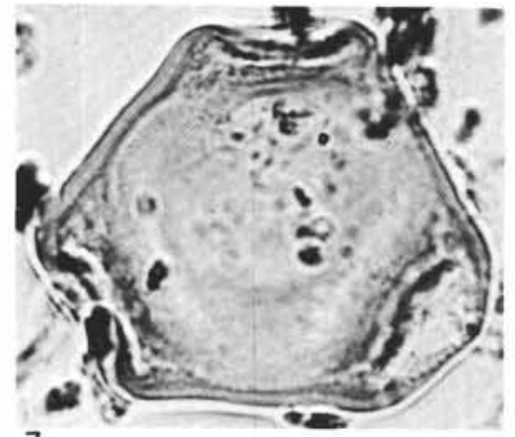

7

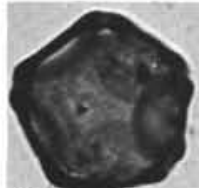

11

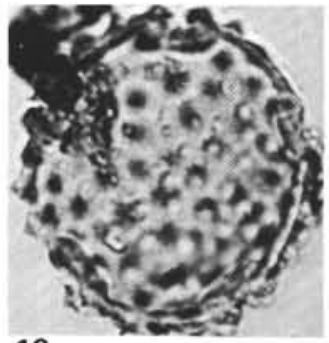

12

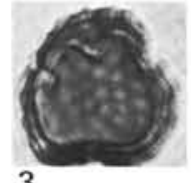

3
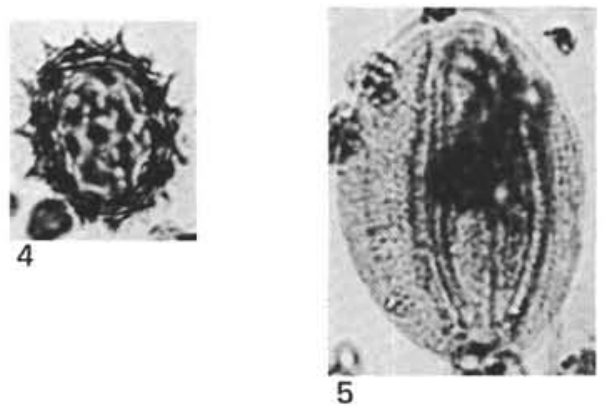

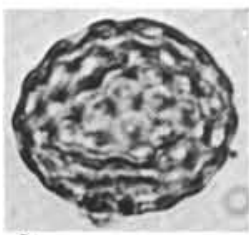

9
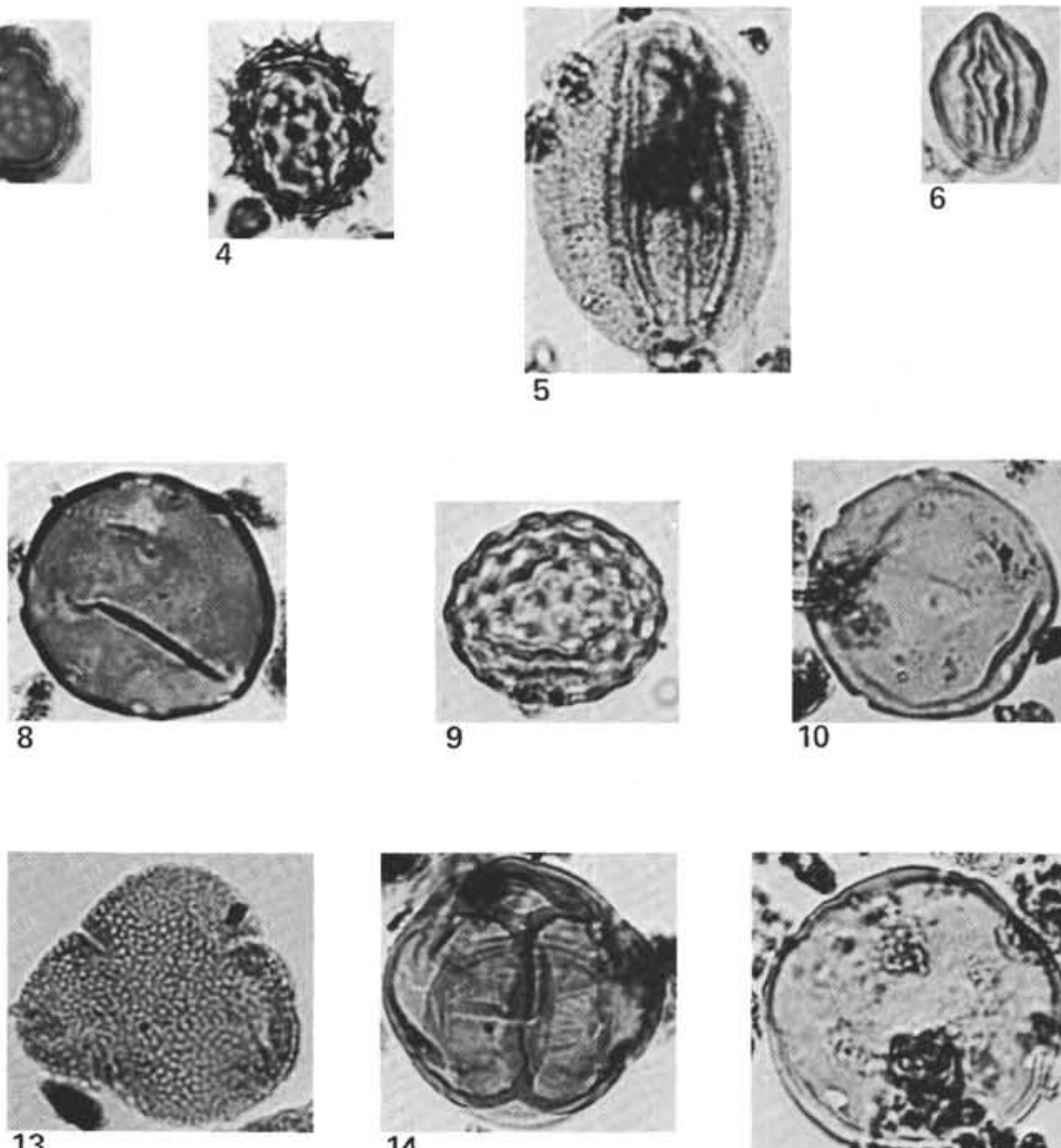

14
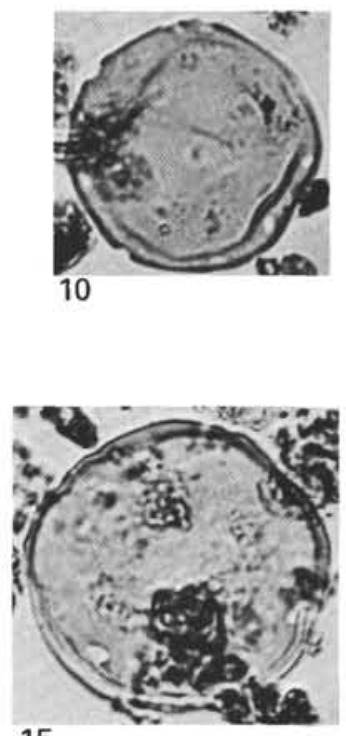

15

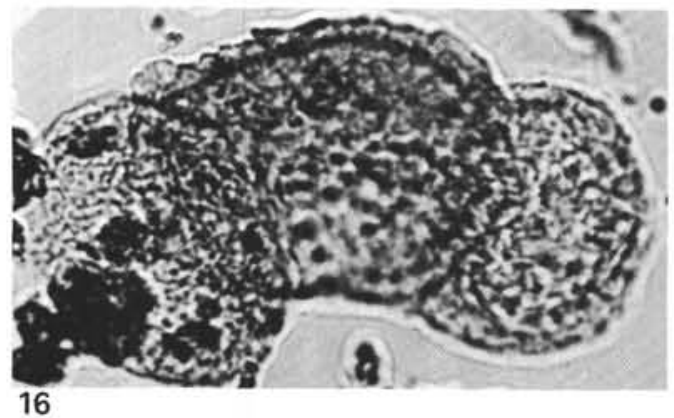

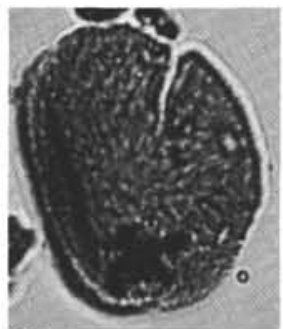

17

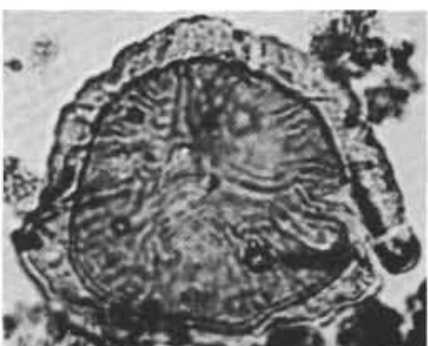

18

Plate 1. All figures are magnified $\times 800$ except Figs. 2 and 3, which are $\times 1000$. 1. Ambrosia sp. 1 (Sample 467-13-2, 20-25 cm). 2. Ambrosia sp. 2 (Sample 467-9-1, 135-140 cm). 3. Ambrosia sp. 1 (Sample 467-6,CC). 4. Compositae sp. 1 (Sample 467-13-2, 20-25 cm). 5. Eriogonum (Sample 467-19-3, 2-7 cm). 6. Castanea (Sample 467-13-2, 20-25 cm). 7. Onagraceae (Sample 467-13-2, 20-25 cm). 8. Pterocarya (Sample 467-13-2, 20-25 cm). 9. Chenopodiaceae (Sample 467-6,CC). 10. Juglans (Sample 467-13-2, 20-25 cm). 11. Alnus (Sample 467-14-3, 10-15 $\mathrm{cm}$ ). 12. Malvaceae (Sample 467-18,CC). 13. Bombacaceae (Sample 467-35-1, 60-65 cm). 14. Ericaceae (Sample 467-80-1, 47-50 cm). 15. Carya (Sample 467-95-1, 10-12 cm). 16. Pinus (Sample 467-51,CC). 17. Polemoniaceae (Sample 467-45,CC). 18. Selaginella (Sample 467-83-2, 90-94 cm). 


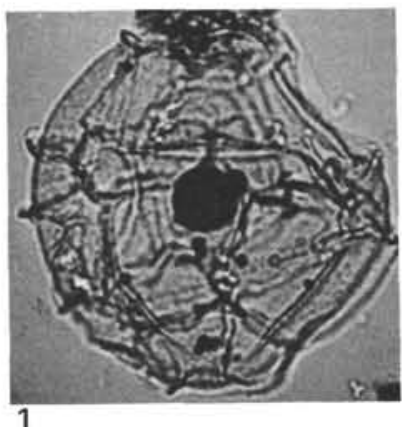

1

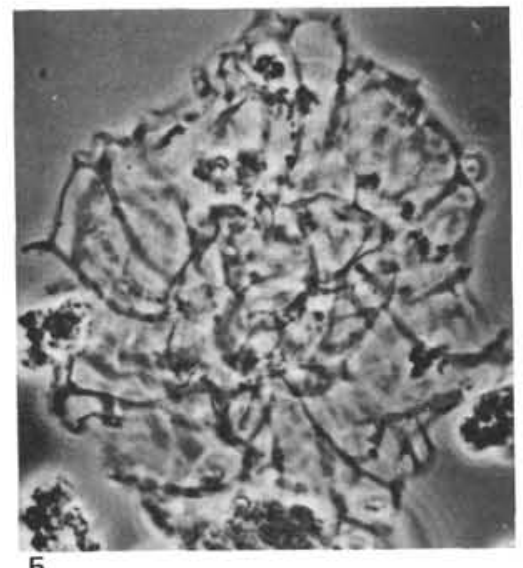

5

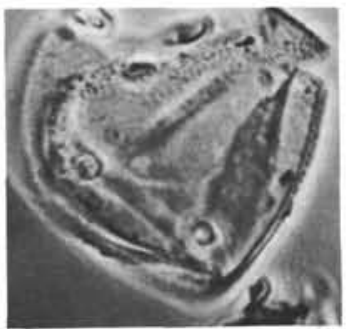

9
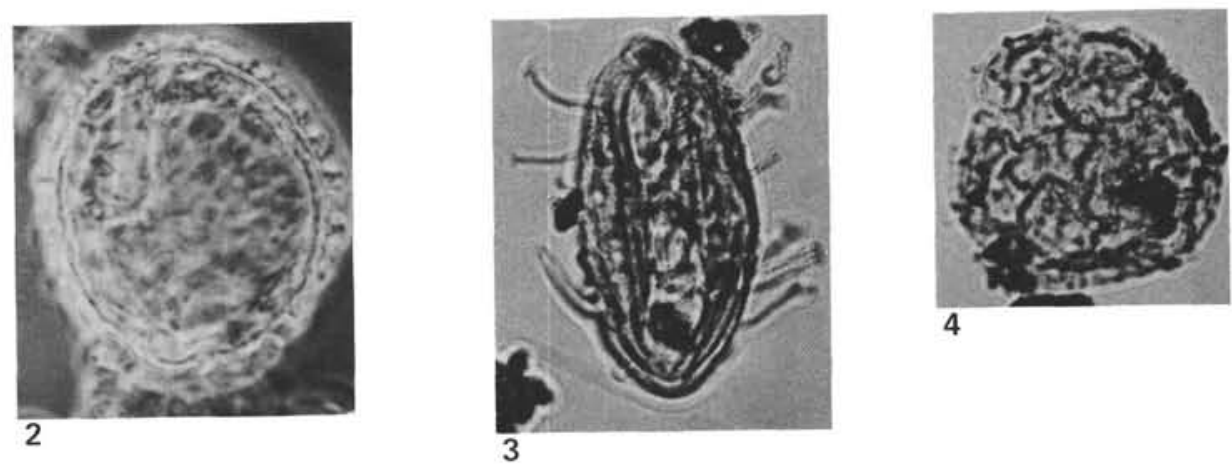

4

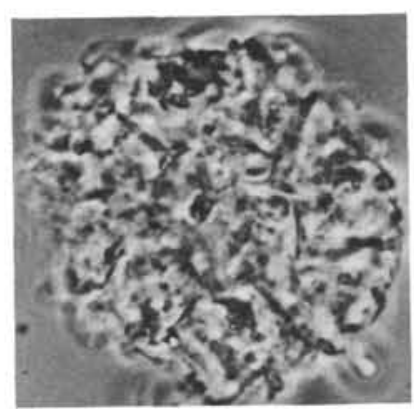

6
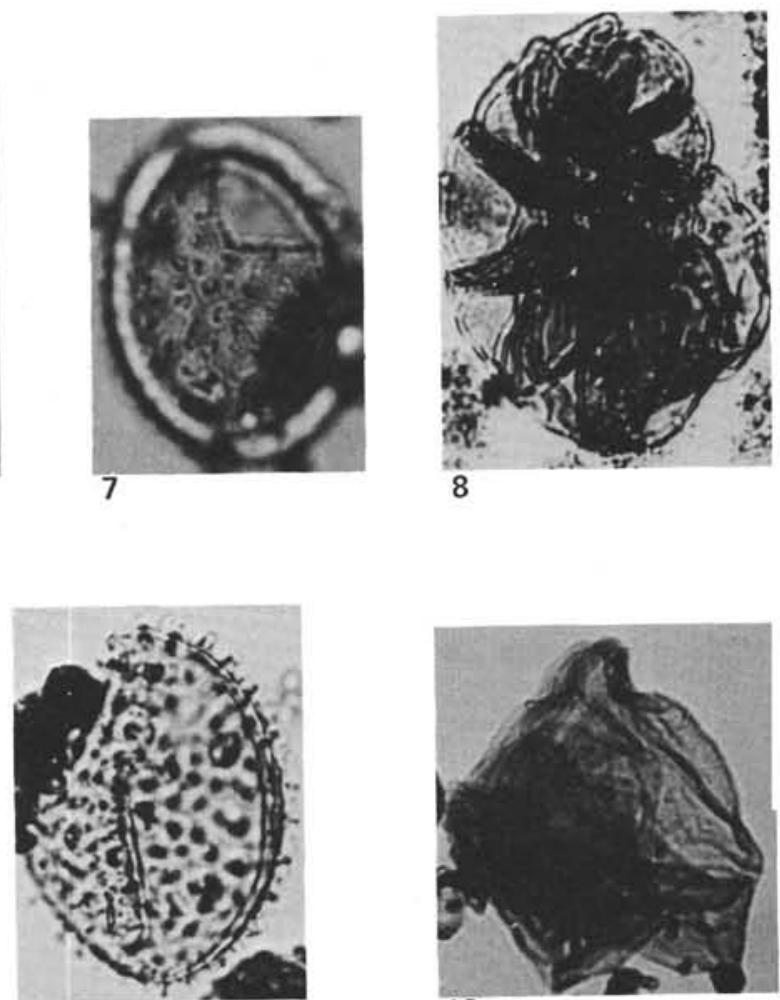

11

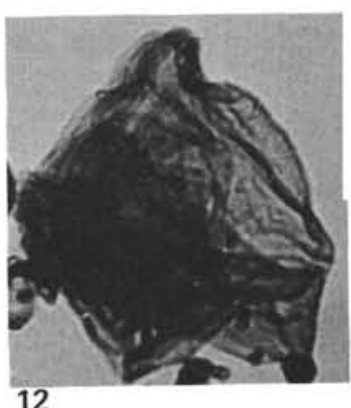

12

Plate 2. All figures are magnified $\times 800$ except Figs. 5, 6, and 9, which are $\times 1000$. 1. Leptodinium sp. (Sample 467-85-2, 137-139 cm). 2. Operculodinium sp. 1 (Sample 467-85-2, 137-139 cm). 3. Operculodinium centrocarpum (Sample 467-25,CC). 4. cf. Microdinium sp. (Sample 467-85-2, 137-139 cm). 5. Cannosphaeropsis sp. A. of Williams and Brideaux (1975) (Sample 467-84-2, 10-12 cm). 6. Cannosphaeropsis sp. A of Williams and Brideaux (1975) (Sample 467-42,CC). 7. Operculodinium sp. 1 (Sample 467-79-2, 145-150 cm). 8. Microforam (Sample 467-85-2, 137-139 cm). 9. Tectatodinium(?) sp. (Sample 467-35-1, 60-65 cm). 10. Leptodinium sp. (Sample 467-85-2, 137-139 cm). 11. Operculodinium sp. 1 (Sample 467-85-2, 137-139 cm). 12. Lejeunia sp. (Sample 467-74,CC). 